\title{
Females with angina pectoris have altered lipoprotein metabolism with elevated cholesteryl ester transfer protein activity and impaired high-density lipoproteins-associated antioxidant enzymes
}

\author{
JUNGHO PARK ${ }^{1}$, JAE-RYONG KIM ${ }^{2}$, DONG-GU SHIN ${ }^{3,4}$ and KYUNG-HYUN CHO ${ }^{1,4}$ \\ ${ }^{1}$ School of Biotechnology, Yeungnam University, Gyeongsan 712-749; ${ }^{2}$ Department of Biochemistry and Molecular Biology, \\ Aging-associated Vascular Disease Research Center, Yeungnam University, Daegu 705-717; ${ }^{3}$ Cardiovascular Division, \\ Internal Medicine, Aging-associated Vascular Disease Research Center, Yeungnam University Medical Center, \\ Daegu 705-717; ${ }^{4}$ Research Institute of Protein Sensor, Yeungnam University, Gyeongsan 712-749, Republic of Korea
}

Received August 10,2011; Accepted September 30, 2011

DOI: $10.3892 / \mathrm{ijmm} .2011 .874$

\begin{abstract}
In order to investigate non-invasive biomarkers for angina pectoris (AP), we analyzed the lipid and protein composition in individual lipoproteins from females with angina pectoris $(n=22)$ and age- and gender-matched controls $(n=20)$. In the low-density lipoprotein (LDL) fraction, the triglycerides (TG) and protein content increased in the AP group compared to the control group. The AP group had lower total cholesterol (TC) and elevated TG in the high-density lipoprotein (HDL) fraction. In the AP group, cholesteryl ester transfer protein (CETP) activity was enhanced in HDL and LDL, while lecithin:cholesterol acyltransferase (LCAT) activity in $\mathrm{HDL}_{3}$ was almost depleted. Antioxidant activity was significantly decreased in the $\mathrm{HDL}_{3}$ fraction, with a decrease in the $\mathrm{HDL}_{2}$ particle size. In the $\mathrm{HDL}_{3}$ fraction, paraoxonase and platelet activating factor-acetylhydrolase (PAF-AH) activity were much lower and the levels of CETP and apoC-III were elevated in the AP group. The LDL from the AP group was more sensitive to cupric ion-mediated oxidation with faster mobility. In conclusion, the lipoprotein fractions in the AP group had impaired antioxidant activity and increased TG and apoC-III with structural and functional changes.
\end{abstract}

\section{Introduction}

Coronary artery syndrome is the most common cause of death among women in developed countries (1). The coronary artery syndrome is initiated by atherosclerosis, which is complexed with dyslipidemia and an inflammatory process.

Angina pectoris (AP) is paroxysmal thoracic pain that is sometimes accompanied by a feeling of suffocation (2).

Correspondence to: Dr Kyung-Hyun Cho, School of Biotechnology, Yeungnam University, Gyeongsan 712-749, Rebublic of Korea E-mail: chok@yu.ac.kr

Key words: angina pectoris, lipoproteins, apolipoproteins, cholesteryl ester transfer protein
AP is most often due to ischemia of the myocardium and is precipitated by effort or excitement. Several biomarkers have been developed to diagnose coronary artery disease, including lipid and inflammatory markers (3), although the markers are not prognostic. It is well-known that the apoB/apoA-I ratio is important to predict the risk of coronary artery disease (CAD) (4). There have been many non-invasive biochemical measures used to predict cardiovascular risk, such as lipid and lipoprotein metabolism, inflammation, and oxidative stress (5-7). Recently, the apolipoprotein composition in lipoprotein and high-density lipoprotein (HDL) sub-fractions has been shown to change in the sera from patients with acute coronary syndrome (ACS). Huang et al (8) reported that plasma ApoAV is associated with ACS. Tashiro et al (9) reported that pre $\beta 1-H D L$ is elevated in patients with unstable angina pectoris. Furthermore, we recently reported an increase in apoC-III in $\mathrm{HDL}_{2}$ from a male with a myocardial infarction (10). Similarly, Lee et al (11) reported that low-density lipoprotein (LDL)-containing apoC-III is an independent risk factor for coronary events in diabetic patients. These findings collectively raised the possibility of a relationship between increased lipid and apoC-III, oxidative modification, and inflammatory processes. In ACS, oxidative stress constitutes an integral part of plaque rupture and platelet activation (12). The oxidative modification of LDL, which is considered a strong risk factor for atherosclerosis and ACS, occurs through the release of pro-inflammatory and oxidative signals. The composition and functional correlations of HDL is also associated with the incidence of metabolic syndrome as described in our previous report (13). Elevated triglycerides (TG) and low cholesterol (C) content in HDL is a major characteristic of the metabolic syndrome (14) and of myocardial infarction (MI) (10). A low HDL-C level is the most common lipid abnormality observed in families with premature coronary heart disease (CHD) (15).

There have been many studies attempting to establish noninvasive biomarkers for the early detection of risk for CHD, including AP and MI. In the current study, to detect unique parameters in lipoprotein levels, lipid and apolipoprotein compositions, and enzyme activities were analyzed between females with AP and controls. 


\section{Materials and methods}

Patients and controls. Female patients with stable AP $(n=22)$ were selected using the following criteria: the presence of chest or arm discomfort that is rarely described as pain, but is reproducibly associated with physical exertion or stress and relieved within 5-10 min of rest and/or administration of sublingual nitroglycerin. The diagnosis was confirmed with a treadmill exercise test and coronary angiography in all patients. Patients did not take any medications, except for statins, prior to hospitalization. Age- and gender-matched reference subjects $(n=20)$ were recruited from healthy volunteers who underwent regular health evaluations at the Health Center of Yeungnam University Hospital (Daegu, Korea). They had unremarkable medical records without a history of endocrinological disorders. Heavy alcohol consumers ( $>30 \mathrm{~g} \mathrm{EtOH} /$ day) and those who had taken prescribed drugs to treat hyperlipidemia, diabetes mellitus, or hypertension were excluded. Informed consent was obtained from all patients and the control group prior to enrollment in the study. The Institutional Review Board at the Medical Center of Yeungnam University approved the protocol.

Isolation of lipoproteins. After overnight fasting, blood was collected using a vacutainer (BD Bio Sciences, Franklin Lakes, NJ, USA) containing EDTA (final concentration, $1 \mathrm{mM}$ ). Plasma was isolated by low-speed centrifugation and stored at $-80^{\circ} \mathrm{C}$ until analysis.

Very low-density lipoproteins (VLDL, $\mathrm{d}<1.019 \mathrm{~g} / \mathrm{ml}$ ), LDL $(1.019<\mathrm{d}<1.063), \mathrm{HDL}_{2}(1.063<\mathrm{d}<1.125)$ and $\mathrm{HDL}_{3}$ $(1.125<\mathrm{d}<1.225)$ were isolated from individual patient and control sera via sequential ultracentrifugation (16), with the density adjusted by the addition of $\mathrm{NaCl}$ and $\mathrm{NaBr}$ in accordance with standard protocols. Samples were centrifuged for $24 \mathrm{~h}$ at $10^{\circ} \mathrm{C}$ at $100,000 \mathrm{xg}$ using a Himac CP $90 \alpha$ (Hitachi, Tokyo, Japan) at the Instrumental Analysis Center of Yeungnam University.

For each of the lipoproteins which were individually purified, total cholesterol (TC) and TG measurements were obtained using commercially available kits (cholesterol, T-CHO, and TG, Cleantech TS-S; Wako Pure Chemical, Osaka, Japan). The protein concentrations of lipoproteins were determined via the Lowry protein assay, as modified by Markwell et al (17) using the Bradford assay reagent (Bio-Rad, Seoul, South Korea) with bovine serum albumin (BSA) as a standard. To assess the degree of oxidation of individual LDL, the concentration of oxidized species in LDL was determined by the thiobarbituric acid reactive substances (TBARS) method using malondialdehyde (MDA) as a standard (18).

Ferric reducing ability of plasma assay. The ferric reducing ability of plasma (FRAP) was determined using the method described by Benzie and Strain (19) with a slight modification, as described previously (20). The antioxidant activities of the individual HDL fractions ( $20 \mu \mathrm{g}$ each) were then estimated by measuring the increase in absorbance induced by the generated ferrous ions.

Cholesteryl ester conversion assay. Cholesteryl ester conversion was performed via lecithin:cholesterol acyltransferase (LCAT) assays, as previously described (21). An equal amount of individual lipoproteins (in $50 \mu \mathrm{l}$ ) from each patient was utilized as the enzyme source. ApoA-I-rHDL containing radiolabeled cholesterol $\left(1 \mu \mathrm{Ci}\right.$ of $\left[{ }^{14} \mathrm{C}\right]-4$-cholesterol $/ 69 \mu \mathrm{g}$ of cholesterol/1 mg of apoA-I) was used as a substrate, and the apoA-I was then expressed using an E. coli expression system, as described previously (21). Discoidal rHDL was prepared via the sodium cholate dialysis method using initial molar ratios of palmitoyloleoyl phosphatidylcholine (POPC)-cholesterolapoA-I-sodium cholate at a ratio of 95:5:1:150 (wt/wt/wt/wt). The reaction was initiated by the addition of individual serum, and the mixture was then incubated for $1 \mathrm{~h}$ at $37^{\circ} \mathrm{C}$. Next, the esterified cholesterol and free cholesterol were separated via thin layer chromatography, and the activity was expressed as the percentage conversion rate of cholesteryl ester from free cholesterol.

Cholesteryl ester transfer assay. An rHDL-containing apoA-I and cholesteryl oleate was synthesized in accordance with the method described by Cho (20) using trace amounts of $\left[{ }^{3} \mathrm{H}\right]$-cholesteryl oleate (TRK886, $3.5 \mu \mathrm{Ci} / \mathrm{mg}$ of apoA-I; GE Healthcare) with a slight modification (22). The CE-transfer reaction was allowed in $300 \mu 1$ reaction mixtures that contained equal amounts of the individual lipoproteins ( $20 \mu 1,10-20 \mu \mathrm{g}$ of protein) as a cholesteryl ester transfer protein (CETP) source and rHDL-agarose (50 $\mu 1,0.25 \mathrm{mg} / \mathrm{ml})$ and human LDL (50 $\mu 1$, $0.25 \mathrm{mg} / \mathrm{ml}$ ) as a CE-donor and CE-acceptor, respectively. After incubation at $37^{\circ} \mathrm{C}$, the reaction was halted via brief centrifugation $(10,000 \mathrm{x} \mathrm{g})$ for $3 \mathrm{~min}$ at $4^{\circ} \mathrm{C}$. The supernatant $(150 \mu \mathrm{l})$ was then subjected to scintillation counting, and the percentage transfer of $\left[{ }^{3} \mathrm{H}\right]-\mathrm{CE}$ from rHDL to LDL was calculated.

Paraoxonase assay. Paraoxonase-1 (PON-1) activity toward paraoxon was determined by evaluating the hydrolysis of paraoxon into $p$-nitrophenol and diethylphosphate, which was catalyzed by the enzyme (23). PON-1 activity was then determined by measuring the initial velocity of $p$-nitrophenol production at $37^{\circ} \mathrm{C}$, as determined by measuring the absorbance at $405 \mathrm{~nm}$ (microplate reader, Bio-Rad model 680; Bio-Rad, Hercules, CA, USA), as described previously (13).

Platelet activating factor-acetylhydrolase (PAF-AH) assay. The individual lipoprotein fractions $(10 \mu \mathrm{l}, 20 \mu \mathrm{g})$ were used as an enzyme source for the PAF-AH reaction with an Lp-PLA ${ }_{2}$ assay conducted according to the method described by Boyd et al (24). Briefly, $\left[{ }^{3} \mathrm{H}\right]$-platelet activating factor (hexadecyl-2-acetyl sn-glyceryl-3-phosphorylcholine, NET910, $0.1 \mathrm{mCi} / \mathrm{ml}$; Perkin-Elmer Life and Analytical Sciences, Boston, MA, USA) and 1-O-hexadecyl-2-acetyl-sn-glycero-3-phosphocholine were used as substrates for the reaction. A substrate solution containing $10 \mu \mathrm{l}$ of [ $\left.{ }^{3} \mathrm{H}\right]-\mathrm{PAF}(1 \mu \mathrm{Ci}, 50 \mu \mathrm{M})$ and $12 \mu \mathrm{M}$ of cold PAF was incubated using each HDL solution as a source for $30 \mathrm{~min}$. The reaction was then stopped by vortexing the solutions with $600 \mu \mathrm{l}$ of $\mathrm{CHCl}_{3}: \mathrm{MeOH}(2: 1, \mathrm{v} / \mathrm{v})$, after which the aqueous layer $(150 \mu \mathrm{l})$ was removed. The aqueous layer was then vortexed again with $\mathrm{CHCl}_{3}$, after which it was centrifuged and the upper phase was used for scintillation counting.

Electromobility of lipoproteins. In order to compare the electromobility of the patient and control samples, the migration of each lipoprotein (LDL, $\mathrm{HDL}_{2}$ and $\mathrm{HDL}_{3}$ ) was evaluated by 
Table I. Lipid and protein composition of lipoproteins from patients.

\begin{tabular}{|c|c|c|c|c|c|c|}
\hline & \multicolumn{3}{|c|}{ Angina pectoris $(n=22)$} & \multicolumn{3}{|c|}{ Control $(n=20)$} \\
\hline & $\begin{array}{c}\mathrm{TC} \\
(\mathrm{mg} / \mathrm{dl})\end{array}$ & $\begin{array}{c}\mathrm{TG} \\
(\mathrm{mg} / \mathrm{dl})\end{array}$ & $\begin{array}{c}\mathrm{TP} \\
(\mathrm{mg} / \mathrm{ml})\end{array}$ & $\begin{array}{c}\mathrm{TC} \\
(\mathrm{mg} / \mathrm{dl})\end{array}$ & $\begin{array}{c}\mathrm{TG} \\
(\mathrm{mg} / \mathrm{dl})\end{array}$ & $\begin{array}{c}\mathrm{TP} \\
(\mathrm{mg} / \mathrm{dl})\end{array}$ \\
\hline VLDL & $120 \pm 64$ & $203 \pm 140$ & $2.8 \pm 0.1$ & $130 \pm 31$ & $243 \pm 46$ & $2.8 \pm 0.1$ \\
\hline LDL & $1095 \pm 231$ & $256 \pm 65^{\mathrm{a}}$ & $6.6 \pm 0.2$ & $909 \pm 177$ & $165 \pm 15$ & $5.5 \pm 1.3$ \\
\hline $\mathrm{HDL}_{2}$ & $46 \pm 14^{\mathrm{a}}$ & $82 \pm 24^{a}$ & $2.0 \pm 0.1$ & $75 \pm 14$ & $52 \pm 28$ & $1.8 \pm 0.1$ \\
\hline $\mathrm{HDL}_{3}$ & $64 \pm 16$ & $16 \pm 7$ & $3.6 \pm 0.5$ & $58 \pm 22$ & $24 \pm 22$ & $3.8 \pm 0.1$ \\
\hline
\end{tabular}

${ }^{\mathrm{a}} \mathrm{P}<0.05$ vs. control. VLDL, very low-density lipoprotein; LDL, low-density lipoprotein; HDL, high-density lipoprotein; TC, total cholesterol; TG, triacylglycerol; TP, total protein.

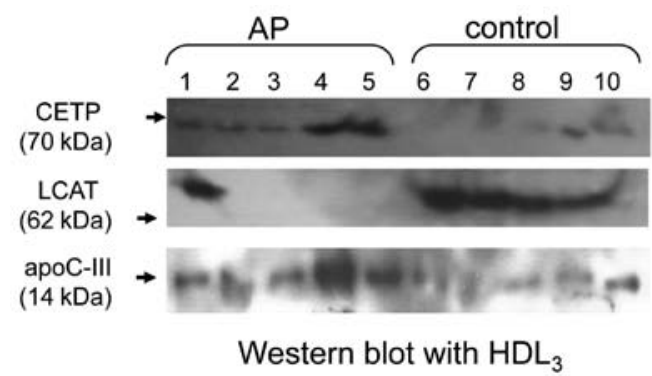

Figure 1. Immunodetection of apolipoproteins and enzymes in $\mathrm{HDL}_{3}$ between the angina pectoris (AP) and control groups. Equal amounts of $\mathrm{HDL}_{3}(6 \mu \mathrm{g}$ of protein) from an individual subject were loaded per lane. Polyclonal CETP antibody (Abcam, ab19012), apoC-III antibody (Chemicon, AB821), and LCAT antibody (Abcam, ab786) were used as primary antibodies.

agarose electrophoresis. The gels were then dried and stained with $0.125 \%$ Coomassie Brilliant Blue, after which the relative band intensities were compared via band scanning using Gel Doc ${ }^{\circledR}$ XR (Bio-Rad) with Quantity One software (version 4.5.2).

Western blot analysis. The apolipoprotein/lipoprotein compositions were compared via sodium dodecyl sulfate-polyacylamide gel electrophoresis (SDS-PAGE) with identical protein loading quantities ( $6 \mu \mathrm{g}$ of total protein per lane) from individual $\mathrm{HDL}_{3}$, and the levels of expression of apolipoprotein were analyzed via immunodetection. Anti-human apoC-III antibody (AB821) was purchased from Chemicon (Temecula, CA, USA). Anti-human CETP antibody (ab19012) and LCAT antibody (ab786) were purchased from Abcam (Cambridge, UK). The relative band intensity (BI) was compared via band scanning with Gel Doc ${ }^{\circledR}$ XR (Bio-Rad) using the Quantity One software (version 4.5.2).

Data analysis. All data are expressed as the mean \pm SD from at least three independent experiments with duplicate samples. Data comparisons were assessed by the Student's t-test using the SPSS program (version 14.0; SPSS, Inc., Chicago, IL, USA).

\section{Results}

Lipid and protein composition in lipoprotein. The serum TC concentrations were similar between the groups (204 \pm 57 and $200 \pm 32 \mathrm{mg} / \mathrm{dl}$, respectively), which remained in the normal range, as suggested by the guidelines of the National Cholesterol Education Program (NCEP)-adult treatment panel (ATP)-III. The LDL-C level was similar between the groups $(105 \pm 38$ and $108 \pm 33 \mathrm{mg} / \mathrm{dl}$ for the AP patients and controls, respectively). However, the HDL-C level was slightly lower in the AP patients than the controls. The ratio of HDL-C-to-TC was significantly lower in the AP patients $(34 \pm 2 \%)$ compared to the control group $(40 \pm 4 \%)$. The serum TG level was not significantly different between the groups (136-175 mg/dl).

Properties of lipoprotein are good biomarkers which reflect the progress of cardiovascular and renal disease. As shown in Table I, the AP group had a similar composition of lipid and protein in VLDL with the control group. Although the TC and protein content in LDL was similar between the groups, the TG content in LDL was significantly higher in the AP group (38 $\mathrm{mg}$ of $\mathrm{TG} / \mathrm{mg}$ of TP) compared to the control group (30 $\mathrm{mg}$ of $\mathrm{TG} / \mathrm{mg}$ of TP). In the $\mathrm{HDL}_{2}$ fraction, the AP group had a much lower TC content and a higher TG content (44\% higher TC and $32 \%$ lower TG) than the control group. Immunodetection revealed that the level of expression of apoC-III was elevated in the $\mathrm{HDL}_{3}$ fraction of the AP group (Fig. 1).

CETP and LCAT activity. As shown in Table II, although the CE-transfer activity of the VLDL fraction was similar between the groups ( 2-3\% CE-transfer), the LDL fraction of the AP group had 2-fold increased CE-transfer activity. The CETP activity of the HDL fraction also increased in the AP group (a 70 and $34 \%$ increase for $\mathrm{HDL}_{2}$ and $\mathrm{HDL}_{3}$, respectively), compared to the control. Immunodetection revealed that CETP was highly expressed in the $\mathrm{HDL}_{3}$ fraction of the AP group (Fig. 1).

The LCAT activity was significantly lower in the $\mathrm{HDL}_{3}$ fraction of the AP group, while no difference existed in the $\mathrm{HDL}_{2}$ fraction between the groups. The LCAT activity for $\mathrm{CE}$-conversion from $\mathrm{FC}$ was lowered in the $\mathrm{HDL}_{2}$ fraction in the AP and control groups, as shown in Table II. The level of expression of LCAT was nearly undetectable in the AP group (lane 1-5) except in one patient (Fig. 1).

Antioxidant activity of $H D L_{2}$ and $H D L_{3}$ was decreased in the AP group. The $\mathrm{HDL}_{3}$ from the AP group had weaker antioxidant activity (172\% increase from the initial level) than the control 
A

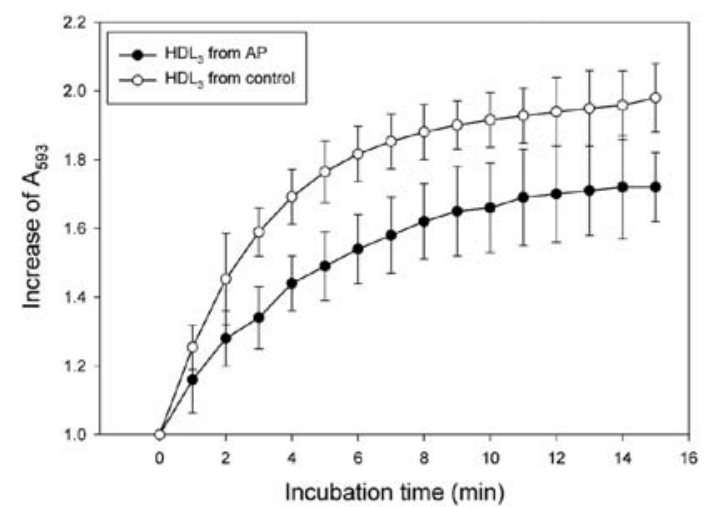

B

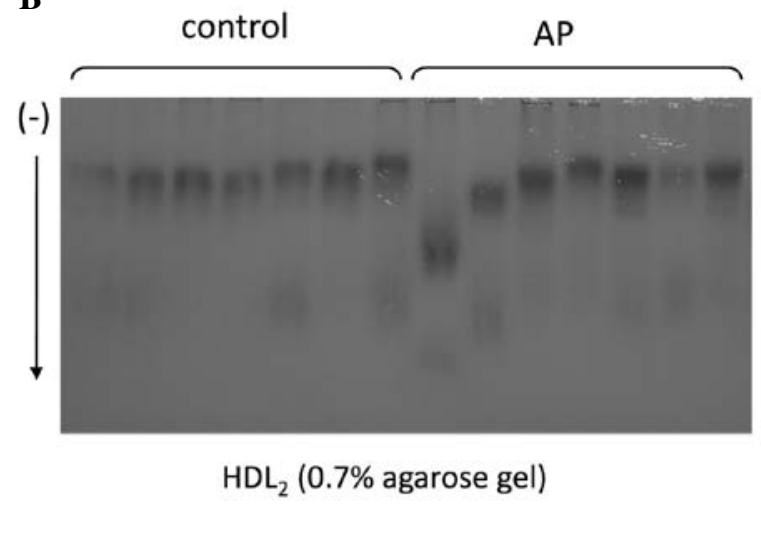

Figure 2. Comparison of the antioxidant activity of HDL. Reduction potential of $\mathrm{HDL}_{3}$ based on the ferric-reducing ability of plasma (FRAP). The same amount of $\mathrm{HDL}_{3}(0.05 \mathrm{ml}, 2 \mathrm{mg} / \mathrm{ml})$ was added to the substrate solution. Comparison of electrophoretic mobility of $\mathrm{HDL}_{2}$ on $0.7 \%$ agarose gels without cupric ion treatment.

Table II. LCAT and CETP activities in lipoprotein fractions.

\begin{tabular}{lcr}
\hline & $\begin{array}{c}\text { Angina } \\
\text { pectoris }(\mathrm{n}=22)\end{array}$ & $\begin{array}{c}\text { Control } \\
(\mathrm{n}=20)\end{array}$ \\
\hline CETP activity $^{\mathrm{a}}$ & & \\
VLDL & $2.6 \pm 0.6$ & $3.1 \pm 0.1$ \\
$\mathrm{LDL}$ & $5.5 \pm 0.3^{\mathrm{c}}$ & $2.0 \pm 1.0$ \\
$\mathrm{HDL}_{2}$ & $17 \pm 2.1^{\mathrm{c}}$ & $10 \pm 3.6$ \\
$\mathrm{HDL}_{3}$ & $35.4 \pm 6.6^{\mathrm{c}}$ & $26.8 \pm 2.1$ \\
$\mathrm{LCAT}$ activity $^{\mathrm{b}}$ & & \\
$\mathrm{HDL}_{2}$ & $1.2 \pm 0.7$ & $2.0 \pm 1.5$ \\
$\mathrm{HDL}_{3}$ & $3.5 \pm 1.3^{\mathrm{c}}$ & $12.3 \pm 2.1$ \\
\hline
\end{tabular}

${ }^{\mathrm{a} C E T P}$ activity is expressed as \% CE transfer $/ 4 \mathrm{~h}$. ${ }^{\mathrm{b}} \mathrm{LCAT}$ activity is expressed as $\% \mathrm{CE}$ conversion $/ \mathrm{h} / 100 \mu \mathrm{g}$ of protein in $\mathrm{HDL} .{ }^{\mathrm{c}} \mathrm{P}<0.05 \mathrm{vs}$. control. LCAT, lecithin:cholesterol acyltransferase; CETP, cholesteryl ester transfer protein; VLDL, very low-density lipoprotein; LDL, lowdensity lipoprotein; HDL, high-density lipoprotein.

group (198\% increase) when the same amount of protein in $\operatorname{HDL}(1.5 \mathrm{mg} / \mathrm{ml})$ was used as an antioxidant source (Fig. 2A). The extent of oxidation in the native state was compared by relative electrophoretic mobility on $0.7 \%$ agarose gel electrophoresis. The $\mathrm{HDL}_{2}$ from the AP group migrated faster than the control group without cupric ion treatment, indicating that $\mathrm{HDL}_{2}$ of the AP group was more oxidized in the native state (Fig. 2B). More highly oxidized HDL has a faster mobility due to a smaller particle size and an increase in charge. In particular, $\mathrm{HDL}_{2}$ from the AP group was 2-fold more susceptible to cupric ion-mediated oxidation, as shown in Fig. 3, indicating that the antioxidant potential was significantly decreased in the AP group. Specifically, electron microscopy revealed that $\mathrm{HDL}_{2}$ from the AP group had a smaller particle size than the control; $\mathrm{HDL}_{2}$ from the AP group was 18-20 $\mathrm{nm}$ in width and length, while $\mathrm{HDL}_{2}$ from the control group was $22-25 \mathrm{~nm}$ in width and length. These results suggest that more highly oxidized HDL has faster electromobility and reduced particle size.

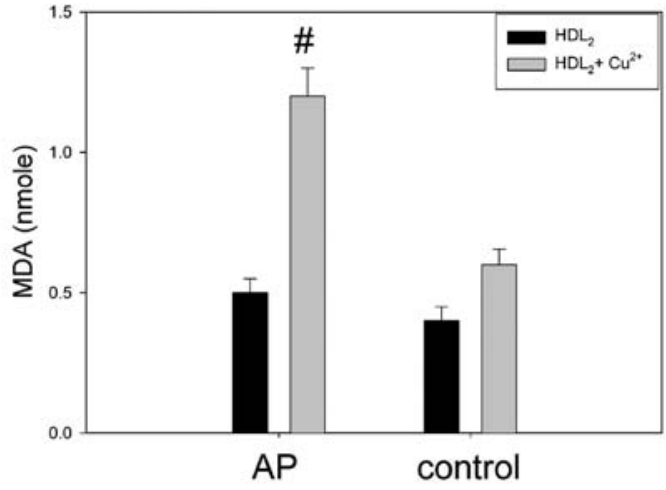

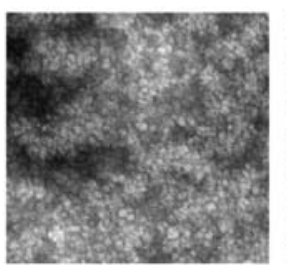

$\mathrm{AP}-\mathrm{HDL}_{2}$

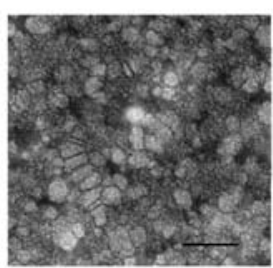

Control-HDL 2
Figure 3. Properties of $\mathrm{HDL}_{2}$ from the AP and control groups. Susceptibility to oxidation in $\mathrm{HDL}_{2}$ by cupric ion treatment (graph). Representative picture of negatively-stained $\mathrm{HDL}_{2}$ from the angina pectoris (AP) and control groups (electron microscopy, bottom photo). All micrographs are shown at a magnification of $x 40,000$. The scale bar corresponds to $100 \mathrm{~nm}$. MDA, malondialdehyde. ${ }^{~} \mathrm{P}<0.01$ vs. the control in the presence of cupric ion.

$H D L$-associated paraoxonase and PAF-AH. The $\mathrm{HDL}_{2}{ }^{-}$ associated PON activity was lower in the AP group than in the control group (112 \pm 10 vs. $164 \pm 25 \mu \mathrm{U} / \mathrm{mg}$ of protein) (Fig. 4A). Moreover, the AP group had a 3 -fold lower $\mathrm{HDL}_{3}$-associated PON activity than the control group $(109 \pm 16$ vs. $561 \pm 36 \mu \mathrm{U} / \mathrm{mg}$ of protein, respectively).

Although there was no significant difference in the $\mathrm{HDL}_{2}$ fraction used as the PAF-AH source, the activity was significantly lower in the AP group when the $\mathrm{HDL}_{3}$ fraction was used (Fig. 4). $\mathrm{HDL}_{3}$ from the AP group showed $40 \%$ less activity than the control group $(15 \pm 2$ and $26 \pm 3$ pmole $\mathrm{PAF} / \mathrm{h} / \mathrm{mg}$ of protein for the AP and control groups, respectively). 


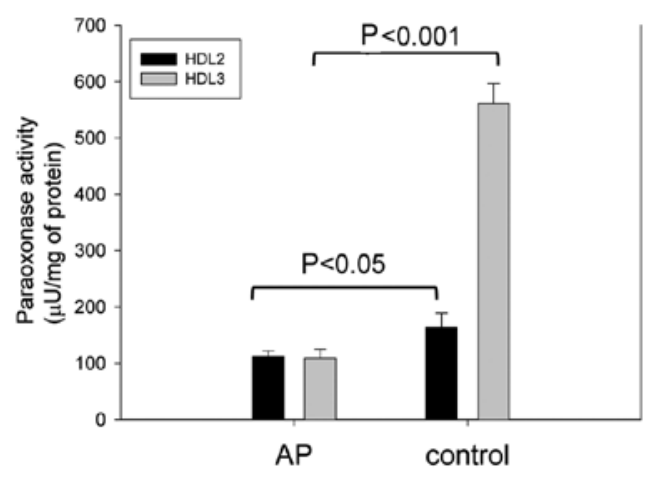

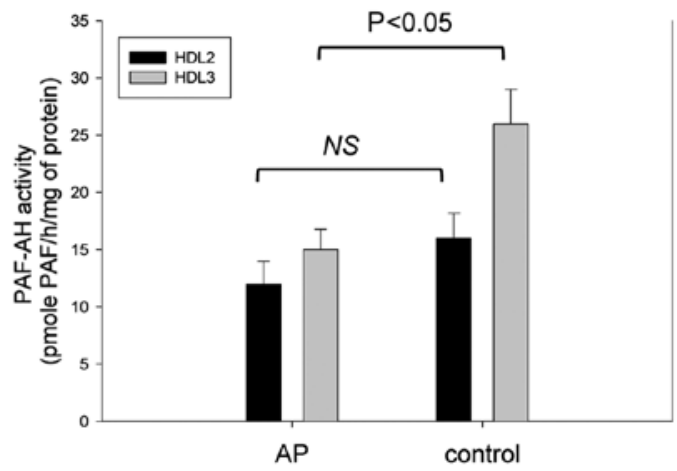

Figure 4. Activities of HDL-associated antioxidant enzymes, (A) paraoxonase and (B) platelet activating factor-acetylhydrolase (PAF-AH), between the angina pectoris (AP) and control groups. An equal amount of individual $\mathrm{HDL}_{2}$ and $\mathrm{HDL}_{3}$ were used as each enzyme source.

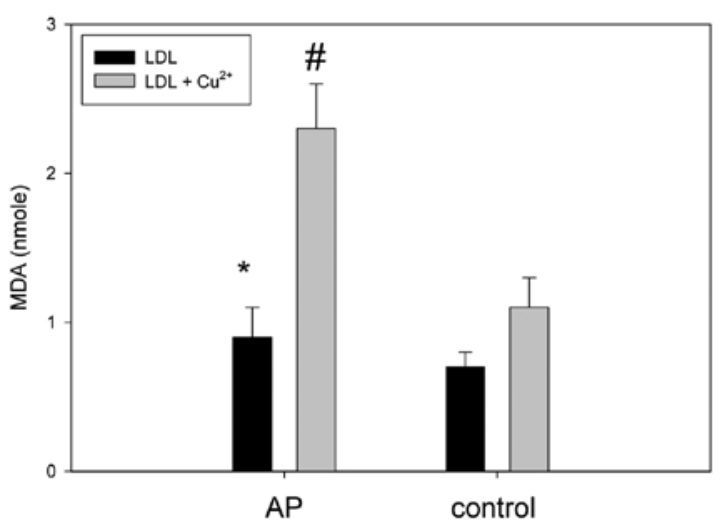

Figure 5. Oxidized extent of LDL with or without cupric ion treatment between the angina pectoris (AP) and control groups. ${ }^{*} \mathrm{P}<0.05$ and ${ }^{\#} \mathrm{P}<0.01$ vs. the control.

LDL from AP patient was more oxidized. The LDL from the AP patient had $\sim 1.8$-fold higher levels of MDA than the control without cupric ion treatment, indicating a greater extent of oxidation of LDL in the AP group in the native state (Fig. 5). Under treatment with cupric ion (final $10 \mu \mathrm{M}$ ), the LDL from the AP and control group showed 2.3 and 1.1 nmole of MDA, respectively, suggesting that the AP group LDL was more sensitive to cupric-ion mediated oxidation.

\section{Discussion}

In addition to a change in serum lipid parameters, lipid and protein compositions in lipoproteins have emerged as a parameter which is associated with the progress of metabolic diseases, such as metabolic syndrome $(13,14)$ and CHD (15). In fact, structural and functional changes in HDL are more dramatic in the acute phase, such as viral infections (25) and after cardiac surgery (26).

Although the AP group had similar levels of TC and LDL-C, the AP group had a lower ratio of HDL-C/TC. While the TC content was lower in $\mathrm{HDL}_{2}$ from the AP group, the TG content was significantly elevated. An increase in TG in the serum is a potent inflammatory factor and is associated with the incidence of CAD (27). Accumulation of serum TG in HDL has been correlated with the incidence of cardiovascular disease $(4,10)$. TG-enriched lipoprotein is more inflammatory in vascular events (28). An elevated TG/HDL-C ratio is associated with increased insulin resistance and cardiovascular events (29). The current report suggests that the serum TG was more highly accumulated in the $\mathrm{LDL}$ and $\mathrm{HDL}_{2}$ fractions, rather than in the VLDL fraction, which is similar to the results of a previous report involving a male MI patient (10) that showed a strong and consistent association of hypertriglyceridemia with enriched LDL fraction. Recently, TG/ HDL-C was shown to be a strong independent predictor of mortality in women with an ischemia syndrome (4). Several reports have suggested that an increased TG level is associated with elevation of apoC-III in lipoproteins; apoC-III in VLDL and LDL is linked with CHD and senescence $(11,30)$. In the current study, TG in $\mathrm{HDL}_{2}$ and LDL, and CETP activity were elevated in AP patients, suggesting that apoC-III in HDL is also a risk factor for coronary events in female AP patients (Table I and Fig. 1).

It is known that serum CETP is an atherogenic factor. CETP promotes the transfer of CE from HDL to VLDL and LDL in exchange for TG, which moves in the opposite direction. The exchange of CE and TG between lipoproteins is linked to elevated levels of TG-enriched lipoprotein, which is pro-inflammatory and pro-atherogenic (31). CETP is an independent risk factor for CHD and metabolic syndrome (32). In addition, we recently reported that the metabolic syndrome in male patients is characterized by a $38 \%$ higher serum cholesteryl ester transfer protein (CETP) activity than the control group (10). The increase in TG is also associated with elevated level of apoC-III in the serum and lipoproteins in male MI patients (10). Furthermore, CETP activity is not decreased when apoC-III-enriched HDL is used as a CETP source (20). The current report showed that the AP group had an elevated level of apoC-III in $\mathrm{HDL}_{3}$.

With the alteration in the lipid content in HDL, many reports have suggested that HDL particle size is associated with cardiovascular events (9). Zeller et al (33) proposed that the smaller particle size of HDL is associated with young age in patients with acute MI. In addition, Arsenault et al (34) reported that a decreased HDL particle size is associated with 
an adverse cardiometabolic risk profile. They also proposed that a small HDL particle size was associated with an increased CHD risk. Interestingly, the HDL particle size was inversely related to CETP activity, serum TG concentration, body mass index, and C-reactive protein.

One of the beneficial virtues of HDL is exerting antioxidant activity. The increase in oxidation susceptibility in the AP group might be linked to alteration of lipid and protein composition in HDL. In the AP group, $\mathrm{HDL}_{2}$-TC was $\sim 40 \%$ lower than the control, while $\mathrm{HDL}_{2}$-TG was elevated by $60 \%$. Moreover, LCAT activity in $\mathrm{HDL}_{2}$ and $\mathrm{HDL}_{3}$ was 40 and $72 \%$ lower in the AP group, respectively, compared to the control. Using immunodetection techniques, LCAT expression was undetectable in the $\mathrm{HDL}_{3}$ fraction of the AP group with the exception of one patient, while the LCAT band was detected in the control (Fig. 1). The decrease in LCAT activity and expression may contribute to the loss of antioxidant activity and oxidation sensitivity.

In addition, human serum PON (EC 3.1.1.2) is an HDL-associated calcium-dependent enzyme, and has strong antioxidant activity. It catalyzes the hydrolysis of oxidized fatty acids from phospholipids and prevents the accumulation of oxidized lipids in lipoproteins, particularly LDL (23). PON activity and -SH levels have been shown to be lower in CAD patients (35), which suggests that reduced PON activity may contribute to the severity of CAD. PAF-AH (EC 3.1.1.47) is also involved in the antioxidant and anti-inflammatory functions associated with the surfaces of HDL (36), and is a $\mathrm{Ca}^{2+}$-independent enzyme belonging to group 7 of the $\mathrm{PLA}_{2}$ family (37). PAF-AH degrades oxidized phospholipids and platelet activating factor, which is a pro-inflammatory factor. Thus, PAF-AH may function as a profoundly anti-atherogenic enzyme. These three enzymes were coincidentally lowered in the HDL fraction of the AP group, which is in good agreement with decreased antioxidant activity.

In conclusion, the current results strongly support the interrelationship between CETP activity, the serum TG level and its distribution, apoC-III expression, and that the change in HDL particle size and antioxidant ability are intimately correlated, especially in the onset of the female with AP.

\section{Acknowledgements}

This study was supported by the National Research Foundation (NRF) through the Aging-associated Vascular Disease Research Center at Yeungnam University [R13-2005-00501003-0 (2010)]. The authors thank Jinwoo Hong, Wonil Choi, Jungwon Lee, Jaemin Jeon, Youngseok Lee and Jinwook Bae at Chunma Honors School of Yeungnam University for their helpful technical assistance.

\section{References}

1. Rosamond W, Flegal K, Furie K, Go A, Greenlund K, Haase N, Hailpern SM,Ho M,Howard V,Kissela B, KittnerS,Lloyd-Jones D, McDermott M, Meigs J, Moy C, Nichol G, O'Donnell C, Roger V, Sorlie P, Steinberger J, Thom T, Wilson M and Hong Y; American Heart Association Statistics Committee and Stroke Statistics Subcommittee: Heart disease and stroke statistics- 2008 update: a report from the American Heart Association Statistics Committee and Stroke Statistics Subcommittee. Circulation 117: e25-e146, 2008.
2. Cannon C and Braunwald E: Unstable angina and non-ST elevation myocardial infarction In: Harrison's Principles of Internal Medicine. Kasper DL, Braunwald E, Fauci AS, Hauser SL, Longo DL and Jameson JL (eds). 16th edition. McGraw-Hill, New York, pp.1444-1448, 2005.

3. Jawad E and Arora R: Chronic stable angina pectoris. Dis Mon 54: 671-689, 2008

4. Bittner V, Johnson BD, Zineh I, Rogers WJ, Vido D, Marroquin OC, Bairey-Merz CN and Sopko G: The triglyceride/ high-density lipoprotein cholesterol ratio predicts all-cause mortality in women with suspected myocardial ischemia: a report from the Women's Ischemia Syndrome Evaluation (WISE). Am Heart J 157: 548-555, 2009.

5. Thygesen K, Alpert JS, White HD; Joint ESC/ACCF/AHA/ WHF Task Force for the Redefinition of Myocardial Infarction, Jaffe AS, Apple FS, Galvani M, Katus HA, Newby LK, Ravkilde J, Chaitman B, Clemmensen PM, Dellborg M, Hod H, Porela P, Underwood R, Bax JJ, Beller GA, Bonow R, Van der Wall EE, Bassand JP, Wijns W, Ferguson TB, Steg PG, Uretsky BF, Williams DO, Armstrong PW, Antman EM, Fox KA, Hamm CW, Ohman EM, Simoons ML, Poole-Wilson PA, Gurfinkel EP, Lopez-Sendon JL, Pais P, Mendis S, Zhu JR, Wallentin LC, Fernández-Avilés F, Fox KM, Parkhomenko AN, Priori SG, Tendera M, Voipio-Pulkki LM, Vahanian A, Camm AJ, De Caterina R, Dean V, Dickstein K, Filippatos G, FunckBrentano C, Hellemans I, Kristensen SD, McGregor K, Sechtem U, Silber S, Tendera M, Widimsky P, Zamorano JL, Morais J, Brener S, Harrington R, Morrow D, Lim M, Martinez-Rios MA, Steinhubl S, Levine GN, Gibler WB, Goff D, Tubaro M, Dudek D and Al-Attar N: Universal definition of myocardial infarction. Circulation 116: 2634-2653, 2007.

6. Walldius $G$ and Jungner I: Is there a better marker of cardiovascular risk than LDL cholesterol? Apolipoproteins B and A-I-new risk factors and targets for therapy. Nutr Metab Cardiovasc Dis 17: 565-571, 2007.

7. Tsimikas S, Willerson JT and Ridker PM: C-Reactive protein and other emerging blood biomarkers to optimize risk stratification of vulnerable patients. J Am Coll Cardiol 47: C19-C31, 2006.

8. Huang XS, Zhao SP, Zhang Q, Bai L and Hu M: Elevated plasma apolipoprotein AV in acute coronary syndrome is positively correlated with triglyceride and C-reactive protein. Chin Med J (Engl) 122: 1408-1412, 2009.

9. Tashiro J, Miyazaki O, Nakamura Y, Miyazaki A, Fukamachi I, Bujo $\mathrm{H}$ and Saito Y: Plasma pre beta1-HDL level is elevated in unstable angina pectoris. Atherosclerosis 204: 595-600, 2009.

10. Cho KH, Shin DG, Baek SH and Kim JR: Myocardial infarction patients showed altered lipoprotein properties and functions when compared with stable angina pectoris patients. Exp Mol Med 41: 67-76, 2009.

11. Lee SJ, Campos H, Moye LA and Sacks FM: LDL containing apolipoprotein CIII is an independent risk factor for coronary events in diabetic patients: Arterioscler Thromb Vasc Biol 23: $853-858,2003$.

12. Hartford M, Wiklund O, Mattsson Hultén L, Persson A, Karlsson T, Herlitz J and Caidahl K: C-reactive protein, interleukin-6, secretory phospholipase A group IIA and intercellular adhesion molecule-1 in the prediction of late outcome events after acute coronary syndromes. J Intern Med 262: 526-536, 2007.

13. Park KH, Shin DG, Kim JR and Cho KH: The functional and compositional properties of lipoproteins are altered in patients with metabolic syndrome with increased cholesteryl ester transfer protein activity. Int J Mol Med 25: 129-136, 2010.

14. McLaughlin T, Abbasi F, Cheal K, Chu J, Lamendola C and Reaven G: Use of metabolic markers to identify overweight individuals who are insulin resistant. Ann Intern Med 139: 802-809, 2003.

15. Genest JJ Jr, Martin-Munley SS, McNamara JR, Ordovas JM, Jenner J, Myers RH, Silberman SR, Wilson PW, Salem DN and Schaefer EJ: Familial lipoprotein disorders in patients with premature coronary artery disease. Circulation 85: 2025-2033, 1992.

16. Havel RJ, Eder HA and Bragdon JH: The distribution and chemical composition of ultracentrifugally separated lipoproteins in human serum. J Clin Invest 34: 1345-1353, 1955.

17. Markwell MA, Haas SM, Bieber LL and Tolbert NE: A modification of the Lowry procedure to simplify protein determination in membrane and lipoprotein samples. Anal Biochem 87: 206-210, 1978.

18. Blois MS: Antioxidant determinations by the use of a stable free radical. Nature 181: 1199-1200, 1958. 
19. Benzie IF and Strain JJ: The ferric reducing ability of plasma (FRAP) as a measure of antioxidant power: the FRAP assay. Anal Biochem 239: 70-76, 1996.

20. Cho KH: Synthesis of reconstituted high-density lipoprotein (rHDL) containing apoA-I and apoC-III: the functional role of apoC-III in rHDL. Mol Cells 27: 291-297, 2009.

21. Han JM, Jeong TS, Lee WS, Choi I and Cho KH: Structural and functional properties of $\mathrm{V} 156 \mathrm{~K}$ and A158E mutants of apolipoprotein A-I in the lipid-free and lipid- bound states. J Lipid Res 46: 589-596, 2005.

22. Cho KH, Lee JY, Choi MS, Cho JM, Lim JS and Park YB: A peptide from hog plasma that inhibits human cholesteryl ester transfer protein. Biochim Biophys Acta 1391: 133-144, 1998.

23. Eckerson HW, Wyte CM and $\mathrm{La} \mathrm{Du} \mathrm{BN}$ : The human serum paraoxonase/arylesterase polymorphism. Am J Hum Genet 35: $1126-1138,1983$.

24. Boyd HF, Fell SC, Flynn ST, Hickey DM, Ife RJ, Leach CA Macphee CH, Milliner KJ, Moores KE, Pinto IL, Porter RA, Rawlings DA, Smith SA, Stansfield IG, Tew DG, Theobald CJ and Whittaker CM: N-1 substituted pyrimidin-4-ones: novel, orally active inhibitors of lipoprotein-associated phospholipase A2. Bioorg Med Chem Lett 10: 2557-2561, 2000.

25. Cho KH, Park SH, Park JE, Kim YO, Choi I, Kim JJ and Kim JR: The function, composition, and particle size of highdensity lipoprotein were severely impaired in an oliguric phase of hemorrhagic fever with renal syndrome. Clin Biochem 41: 56-64, 2008

26. Jahangiri A, de Beer MC, Noffsinger V, Tannock LR, Ramaiah C, Webb NR, van der Westhuyzen DR and de Beer FC: HDL remodeling during the acute phase response. Arterioscler Thromb Vasc Biol 29: 261-267, 2009.

27. McBride PE: Triglycerides and risk for coronary heart disease. J Am Med Assoc 298: 336-338, 2007.

28. Libby P: Fat fuels the flame triglyceride-rich lipoproteins and arterial inflammation. Circulation 100: 299-301, 2007.

29. Ostfeld R, Mookherjee D, Spinelli M, Holtzman D, Shoyeb A Schaefer M, Doddamani S, Spevack D and Du Y: A triglyceride/ high-density lipoprotein ratio $>$ or $=3.5$ is associated with an increased burden of coronary artery disease on cardiac catheterization. J Cardiometab Syndr 1: 13-15, 2006.
30. Park KH, Shin DG, Kim JR and Cho KH: Senescence-related truncation and multimerization of apolipoprotein A-I in highdensity lipoprotein with an elevated level of advanced glycated end products and cholesteryl ester transfer activity. J Gerontol A Biol Sci Med Sci 65: 600-610, 2010.

31. Chapman MJ, Goff WL, Guerin M and Kontush A: Cholesteryl ester transfer protein: at the heart of the action of lipid-modulating therapy with statins, fibrates, niacin, and cholesteryl ester transfer protein inhibitors. Eur Heart J 31: 149-164, 2010.

32. Chapman MJ: Therapeutic elevation of HDL-cholesterol to prevent atherosclerosis and coronary heart disease. Pharmacol Ther 111: 893-908, 2006.

33. Zeller M, Masson D, Farnier M, Lorgis L, Deckert V, Pais de Barros JP, Desrumaux C, Sicard P, Grober J, Blache D, Gambert P, Rochette L, Cottin Y and Lagrost L: High serum cholesteryl ester transfer rates and small high-density lipoproteins are associated with young age in patients with acute myocardial infarction. J Am Coll Cardiol 50: 1948-1955, 2007.

34. Arsenault BJ, Lemieux I, Després JP, Gagnon P, Wareham NJ, Stroes ES, Kastelein JJ, Khaw KT and Boekholdt SM: HDL particle size and the risk of coronary heart disease in apparently healthy men and women: the EPIC-Norfolk prospective population study. Atherosclerosis 206: 276-281, 2009.

35. Gur M, Aslan M, Yildiz A, Demirbag R, Yilmaz R, Selek S, Erel $\mathrm{O}$ and Ozdogru I: Paraoxonase and arylesterase activities in coronary artery disease. Eur J Clin Invest 36: 779-787, 2006.

36. Karasawa K: Clinical aspects of plasma platelet-activating factor-acetylhydrolase. Biochim Biophys Acta 1761: 1359-1372, 2006.

37. Six DA and Dennis EA: The expanding superfamily of phospholipase $\mathrm{A}(2)$ enzymes: classification and characterization. Biochim Biophys Acta 1488: 1-19, 2000. 